\title{
Ingestive behavior and infrared thermography of Holstein $\times$ Zebu crossbreed cows in the final third of gestation in different pastoral environments
}

\author{
Hugo Pereira Santos $^{a}$ (i) | Cinara da Cunha Siqueira Carvalho ${ }^{b *}$ (D) José Reinaldo Mendes Ruas \\ Flávio Pinto Monção ${ }^{\mathrm{b}}$ (D) | Virgílio Mesquita Gomes ${ }^{\mathrm{b}}$ (D) | Edilane Aparecida Silva ${ }^{\mathrm{c}}$ (D) | Maria \\ Dulcinéia da Costa $^{\mathrm{b}}$ (D) Vicente Ribeiro Rocha Júnior ${ }^{\mathrm{b}}$ (D) | Thamara Amaral Diniz ${ }^{\mathrm{b}}$ (D)
}

Universidade Estadual do Sudoeste da Bahia (UESB), Praça da Primavera, 40, Bairro Primavera, CEP: 45.700-000, Itapetinga, BA, Brazil.

${ }^{b}$ Department of Agricultural Sciences, Universidade Estadual de Montes Claros, Rua Reinaldo Viana, 2630, Morada do Sol, CEP: 39448581, Janaúba, Minas Gerais,

Brazil.

'Empresa de Pesquisa Agropecuária de Minas Gerais, Secretaria de Agricultura e Abastecimento de Minas Gerais, Unidade Regional do Triângulo e Alto Paranaíba, Rua Afonso Rato, 1301, Mercês, 38060040, Uberaba, MG, Brazil.

Corresponding author: cinarasiqueira@yahoo.com.br

\begin{abstract}
This study aimed to evaluate the ingestive behavior and body surface temperature of F1 Holstein $\times$ Zebu cows that were non-lactating in the final third of gestation and managed in two pastoral environments. Forty F1 Holstein $\times$ Zebu cows divided into two pastoral environments were evaluated: signal grass (Urochloa decumbens cv. Basilisk) deferred at the beginning of regrowth and pasture of xaraés grass (Urochloa brizantha cv. Xaraés) in vegetative growth in four periods during the day (morning, afternoon, night and dawn), following the completely randomized design in a factorial scheme. Each cow is the experimental unit. The total grazing time was $32.22 \%$ higher in the signal grass than xaraés grass (average of 479.50 minutes). There was an interaction between the pastoral environments and the times of day on the black globe temperature and humidity index (BGHI). In the pasture of signal grass, the BGHI was $19.07 \%$ higher in the morning and afternoon periods than the average (68.95) verified during the night and dawn. F1 Holstein $\times$ Zebu cows grazing time in the final third of gestation is influenced by the pasture condition and not by the climate since they feed in a high BGHI environment.
\end{abstract}

Keywords deferred pasture, non-lactating cows, thermographic analysis, vegetative growth pasture

\section{Introduction}

Brazil has a high incidence of solar radiation and average air temperatures during most of the year. Furthermore, some regions record extended periods of low rainfall. Air temperatures above $25{ }^{\circ} \mathrm{C}$ can cause thermal stress in pure Holstein cows (Bermam et al 1985); however, F1 Holstein $\times$ Zebu animals may exhibit greater tolerance to stressful environments without modifying productivity (Castro et al 2018; Pereira et al 2018). This is because they unite the Holstein breed's productivity and the rusticity of the zebu breeds, conferring these animals' adaptability to the diverse environmental conditions existing in regions of tropical climate (Ruas et al 2014).

Knowledge of cows' behavior in the dry period or of pregnant, non-lactating cows may be an essential strategy to circumvent disturbances at this stage since exposure to stressful situations may compromise subsequent lactation (do Amaral et al 2009; Tao et al 2011; Dahl 2012). In the final third of gestation, there is a natural increase in internal body temperature due to fetal growth, the elevation of internal pressure on the digestive organs, and a decrease in the space occupied by feed. Heat production can be quantified through thermographic analysis to predict thermal discomfort in the animals either because of feed intake or the environment's effects (Laüe and Petersen 1991; Montanholi et al 2008).

Forage plants can become modified in quality according to environmental factors and exhibit seasonality of production; therefore, management strategies such as pasture deferrals can be used to circumvent animal feed restrictions (Santos et al 2009). In the months before the rainy season, sporadic rainfall may occur, causing pasture regrowth and subsequent vegetative growth. Growth conditions and grass structure associated with temperature, humidity, and solar radiation variations throughout the day may influence the ingestive behavior, welfare, and subsequent productivity of crossbred cows (Castelán-Ortega et al 2016; Pereira et al 2018). There are few studies of these factors in the literature using crossbred F1 Holstein $\times$ Zebu cows (Pereira et al 2018).

This study aimed to evaluate the ingestive behavior and body surface temperature of F1 Holstein $\times$ Zebu cows that were non-lactating in the final third of gestation and managed in two pastoral environments.

\section{Materials and Methods}




\subsection{Experimental location}

The experiment was carried out at the Agricultural Research Company of Minas Gerais (EPAMIG), at the Experimental Field of Felixlândia, located in the municipality of Felixlândia, Minas Gerais, at $18^{\circ} 46^{\prime}$ south latitude and $44^{\circ}$ $55^{\prime}$ west longitude. According to the classification of Köppen, the climate in the region is tropical savanna, with two distinct seasons, dry winter and rainy summer. The average annual precipitation is $1.126 \mathrm{~mm}$, the average annual maximum temperatures $29.7{ }^{\circ} \mathrm{C}$, and the average minimum temperatures $16.6^{\circ} \mathrm{C}$.

\subsection{Evaluation of animals and pastures}

Forty non-lactating F1 Holstein $\times$ Zebu cows were evaluated in the final third of gestation, presenting a mean age of $6.14 \pm 1.67$ years, a mean gestation period of $196.15 \pm 9$ days, and a mean weight of $496 \pm 41 \mathrm{~kg}$. The F1 Holstein $x$ Zebu cows were evaluated in two pastoral environments, the first composed of signal grass (Urochloa decumbens cv. Basilisk) with 10 hectares at the beginning of regrowth after being delayed in the autumn-winter. The F1 Holstein $\times$ Zebu cows were subjected to continuous grazing with a fixed stocking rate of 2.1 UA.ha ${ }^{-1}$. The forage availability was 9.25 t.ha of dry matter (DM) $)^{-1}$, the leaf:stem ratio was 0.49 , the volume density forage was $157.55 \mathrm{~kg} . \mathrm{cm} . \mathrm{ha}^{-1}$, the mean grass height was $58.71 \mathrm{~cm}$, and the falling index was 1.69. The cows in this grazing treatment were provided protein supplementation with $40 \%$ crude protein once daily in the morning in uncovered plaster pits installed in the pasture, with an average spacing of 30 centimeters per animal and an average consumption of 280 grams.day $^{-1}$. The second pastoral environment, formed by the pasture of xaraés grass (Urochloa brizantha cv. Xaraés) with 5 hectares under vegetative growth, was submitted the same grazing method but had a higher stocking rate of 4.5 UA.ha $^{-1}$. The forage availability was 9.36 t.ha of $\mathrm{DM}^{-1}$, the leaf:stem ratio was 0.92 , the forage volume density was $200.56 \mathrm{~kg} . \mathrm{cm} . \mathrm{ha}^{-1}$, and the mean pasture height was $46.67 \mathrm{~cm}$. For the cows in this pastoral environment, mineral supplementation was provided in covered troughs. In both pasture conditions, water was available ad libitum. The data of the chemicalbromatological composition of the pastures used are presented in Table 1.

Table 1 Chemical-bromatological composition ( $\mathrm{g}^{\mathrm{kg}} \mathrm{H}^{-1}$ of dry matter) of the pastures used*.

\begin{tabular}{|c|c|c|c|c|c|c|c|c|}
\hline Pastoral environments & DM & Ash & $\mathrm{CP}$ & $\mathrm{EE}$ & NDFap & ADF & LIG & NFC \\
\hline Signal grass $^{1}$ & 511.70 & 57.60 & 50.90 & 19.50 & 683.40 & 369.50 & 51.30 & 188.60 \\
\hline Xaraés grass ${ }^{2}$ & 290.50 & 79.00 & 79.70 & 21.80 & 599.30 & 294.20 & 24.60 & 223.00 \\
\hline
\end{tabular}

*Forage samples collected by manual grazing simulation (De Vries 1995) were analyzed for dry matter (DM; INCT-CA G-003/1), ash (INCT-CA M-001/1), crude protein ( CP; INCT-CA N-001/1), ether extract (EE; INCT-CA G-005/1), neutral detergent fiber (NDF; CA-F-002/1) corrected for ash and protein (INCT-CA N004/1), acid detergent fiber (ADF; INCT-CA F-004/1), lignin (LIG; INCT-CA F-005/1) and non-fibrous carbohydrates (NFC) according to Detmann et al (2012).

${ }^{1}$ Urochloa decumbens cv. Basilisk; ${ }^{2}$ Urochloa brizantha $\mathrm{cv}$. Xaraés.

\subsection{Climate variables}

The climatic environment was characterized during eight consecutive days in each pastoral environment by using two Extech dataloggers, model RHT10, with continuous reading and programmed to carry out the collection every 30 minutes. The dataloggers were used to obtain air temperature $\left({ }^{\circ} \mathrm{C}\right)$, relative humidity $(\%)$, dew point temperature $\left({ }^{\circ} \mathrm{C}\right)$, and black globe temperature $\left({ }^{\circ} \mathrm{C}\right)$. The dataloggers were installed near the pastures at the height of $1.70 \mathrm{~m}$ above the ground. The data were used to calculate the black globe temperature and humidity index (BGHI) according to Buffington et al (1981) using the following mathematical model:

$B G H I=T_{b g}+0.36 \times T_{d p}+41.5$

where: $T_{d p}$ is Dew Point Temperature $\left({ }^{\circ} \mathrm{C}\right)$ and $T_{b g}$ is Black Globe Temperature $\left({ }^{\circ} \mathrm{C}\right)$.

The evaluation of the climatic environment occurred during the collection of data throughout the day. The schedules were grouped into four periods: the morning period being between 07:00 and 11:59, the afternoon period from 12:00 to $17: 59$, the night from 18:00 to $23: 59$, and dawn from 00:00 to 07:59 hours.

\subsection{Ingestive behavior}

The evaluation of ingestive behavior was performed visually by previously trained observers. The F1 Holstein $x$ Zebu cows were submitted to a feed adaptation period with 14- and three-day observations. Behavioral observations were recorded: the animals' time to grazing, rumination, idle, and other activities (water consumption, mineral salt, and protein supplement). The samples were collected every 10 minutes for 24 hours over five consecutive days of observations. The bit rate is calculated during two successive days for nine F1 Holstein $\times$ Zebu cows chosen randomly. Visual observations were made to determine when each animal completed 20 bits of apprehension at five-minute intervals during a three-time period scoring. The highest concentration of animals is dedicated to grazing activity (Forbes and Hodgson 1985).

\subsection{Infrared thermography}

Body surface temperatures were measured using an infrared thermographic camera (Flir ${ }^{\circ}$, model C2), with a 
coefficient of emissivity of 0.98 . Photographic records were taken at a distance of two meters from each animal in the pasture at six times: 08:00, 12:00, 16:00, 20:00,00:00, and 04:00 hours. The images were analyzed later in the FlirQuickReport software, with values obtained for two anatomical regions, the right and left flank, at the beginning and the end of the experiment. The calculation of surface temperature variation of the right and the left flank was performed according to equation 2:

$\Delta$ temperature $=$ Right flank - Left flank

\subsection{Statistical analysis}

The experimental design was completely randomized, with measures repeated in time. A 2x4 factorial scheme was used to characterize the climatic environment, with two treatments (signal grass and xaraés grass) and four periods (morning, afternoon, night, and dawn) during eight consecutive days. A completely randomized design (CRD) was used with repeated measures consisting of two treatments (signal grass and grass of xaraés grass) and 20 repetitions evaluated during five consecutive days to assess ingestive behavior. To measure the bit rate, a design completely randomized was used in a $2 \times 3$ factorial scheme, with two treatments (signal grass and xaraés grass) and three periods (morning, afternoon, and night) with nine replications during two consecutive days. For the thermography analysis, a CRD was used in a $2 \times 6$ factorial scheme, with repeated measures in time, with two treatments (signal grass and grass of xaraés grass) and six times of collection (08:00, 12:00, 16:00, 20:00, 00:00, and 04:00 hours) with 20 replicates evaluated for two consecutive days. Each animal was considered an experimental unit. The data were submitted to analysis of variance using PROC MIXED of SAS (SAS-Institute Inc; Cary; NC; USA). The homogeneity of variances (PROC UNIVARIATE), the residues' normality, and the parameters' additivity were diagnosed. According to the corrected AKAIKE (AIC) information criterion, the covariance matrix that best fit the data was the variance components for all variables analyzed.

For climate conditions and feeding behavior, the study adopted the mathematical model represented by the equation $Y_{i j k}=\mu+T j+$ Perk $+T^{*}$ PER $+\varepsilon i j k$, where $y_{i j k}$ is the average of the dependent variable in the treatment " $i$ " in treatment (T) "j", in the period of day (Per)" k ", $\mu$ is the general average, $T$ is the treatment effect, Per is the periodof-day effect, $T$ * Per is the interaction effect, and cijk is the random error. The treatment, the day's period, and the interaction between treatment/period of the day were considered fixed effects, and the animals were considered random effects. When significant by the F test, the Tukey test compared the means at $5 \%$ probability. For the surface temperature, we adopted the mathematical model represented by the equation $\hat{Y} i j k=\mu+\mathrm{Tj}+\mathrm{Hk}+\mathrm{T}^{*} \mathrm{H}+\varepsilon \mathrm{ijk}$, where $\hat{Y}_{i j k}$ is the mean of the dependent variable in the treatment "i" in the treatment $(T)$ "j" $(H)$ " $k$ ", $\mu$ is the general mean, $\mathrm{T}$ is the treatment effect, $\mathrm{H}$ is the hourly effect, $\mathrm{T} * \mathrm{H}$ is the interaction effect, and rijk is the random error. The treatment, the time of day, and the interaction between treatment/daylight hours were considered fixed effects, and the animals were considered random effects. When significant by the $\mathrm{F}$ test, the Tukey test compared the means at $5 \%$ probability.

\section{Results}

There was an interaction $(P<0.01)$ between the pastoral environments and the periods of the air temperature (Table 2). The highest air temperature average $\left(35.4{ }^{\circ} \mathrm{C}\right)$ was verified among the pasture grass periods in the morning and afternoon. In the xaraés grass pasture, the afternoon's air temperature was $34.79 \%$ higher than the other periods' average $\left(23.86^{\circ} \mathrm{C}\right)$. Signal grass, in the morning and at dawn, presented higher air temperatures than the xaraés grass. There was no interaction $(P>0.05)$ between the pastoral environments and the periods in terms of relative humidity. The relative humidity was $28.76 \%$ higher in the pasture of xaraés grass than in the Signal grass $(46.8 \%)$. Between periods of the day, the greater relative humidity occurred at dawn. There was an interaction between the pastoral environments and the periods on the BGHI. In the pasture grass, the $\mathrm{BGHI}$ was $19.07 \%$ higher in the morning and afternoon than the average (68.95) verified during the night and dawn. In the xaraés grass pasture, the largest and smallest BGHI values were at dawn, respectively.

There was an interaction $(P<0.01)$ between the pastoral environments and the periods for all the activities of ingestive behavior (Table 3). In all periods, the grazing time was higher in the signal grass than in the xaraés grass. The total grazing time was $32.22 \%$ higher in signal grass than in the xaraés grass (average of 479.50 minutes). The highest grazing time in both pastoral environments was observed during the afternoon period. For rumination activity, there was no difference $(P>0.05)$ between the treatments in the morning and at night; however, the afternoon and dawn periods were significantly different $(P<0.05)$.

The afternoon period presented approximately $34 \%$ more time spent on rumination activity in xaraés grass and at $8.5 \%$ at dawn for signal grass. All the periods differed $(P<$ 0.01 ) in both treatments, exhibiting longer rumination times in the morning, followed by at night, with values of approximately $37.7 \%$ and $32.6 \%$, respectively, concerning the total time ( $528 \mathrm{~min}$.) in signal grass. The same behavior could be observed in xaraés grass.

The time spent in idleness was higher in the pasture of xaraés grass, with a total average of $\mathbf{2 1 2 . 7}$ minutes longer than that in signal grass pasture. Idle time was higher at dawn in both pastoral environments $(P<0.05)$, representing $50 \%$ of the signal grass pasture's total activity and $39 \%$ in the xaraés grass pasture. The variable other activities differed between treatments in all periods $(P<0.05)$, except in the morning $(P>0.05)$. The total mean of this variable was 17.3 minutes greater in the signal grass. All the periods differed among signal grass pastures, whereas in xaraés grass, only the afternoon period showed more time dedicated to other activities. 
Table 2 Mean Values of air temperature, relative humidity, and black globe temperature and humidity index (BGHI).

\begin{tabular}{|c|c|c|c|c|c|c|c|}
\hline \multirow{2}{*}{ Period } & \multicolumn{2}{|c|}{ Pastoral environments } & \multirow{2}{*}{ Average } & \multirow{2}{*}{ SEM } & \multicolumn{3}{|c|}{$P$-Value } \\
\hline & Signal grass ${ }^{1}$ & Xaraés grass ${ }^{2}$ & & & $\mathrm{~T}$ & Per & $\mathrm{T} \times \mathrm{Per}$ \\
\hline \multicolumn{8}{|c|}{ Air temperature $\left({ }^{\circ} \mathrm{C}\right)$} \\
\hline Morning & $35.40^{\mathrm{Aa}}$ & $30.80^{\mathrm{Bb}}$ & - & \multirow{4}{*}{0.87} & \multirow{4}{*}{$<0.01$} & \multirow{4}{*}{$<0.01$} & \multirow{4}{*}{$<0.01$} \\
\hline Afternoon & $35.40^{\mathrm{Aa}}$ & $36.60^{\mathrm{Aa}}$ & - & & & & \\
\hline Night & $23.40^{\mathrm{Ab}}$ & $22.30^{\mathrm{Ac}}$ & - & & & & \\
\hline \multirow[t]{2}{*}{ Dawn } & $21.50^{\mathrm{Ab}}$ & $18.50^{\mathrm{Bd}}$ & - & & & & \\
\hline & \multicolumn{2}{|c|}{ Relative humidity (\%) } & & & & & \\
\hline Morning & 35.50 & 57.10 & $45.50^{c}$ & \multirow{4}{*}{2.0} & \multirow{4}{*}{$<0.01$} & \multirow{4}{*}{$<0.01$} & \multirow{4}{*}{$<0.06$} \\
\hline Afternoon & 29.80 & 39.00 & $34.10^{d}$ & & & & \\
\hline Night & 56.30 & 77.60 & $66.30^{\mathrm{b}}$ & & & & \\
\hline Dawn & 65.80 & 89.00 & $76.60^{\mathrm{a}}$ & & & & \\
\hline \multirow[t]{2}{*}{ Averages } & $46.80^{\mathrm{B}}$ & $65.70^{A}$ & & & & & \\
\hline & & & & & & & \\
\hline Morning & $85.00^{\mathrm{Aa}}$ & $81.70^{\mathrm{Bb}}$ & - & \multirow{4}{*}{1.12} & \multirow{4}{*}{$<0.40$} & \multirow{4}{*}{$<0.01$} & \multirow{4}{*}{$<0.01$} \\
\hline Afternoon & $85.40^{\mathrm{Ba}}$ & $92.00^{\mathrm{Aa}}$ & - & & & & \\
\hline Night & $70.20^{\mathrm{Ab}}$ & $71.60^{A c}$ & - & & & & \\
\hline Dawn & $67.70^{\mathrm{Ab}}$ & $65.80^{\mathrm{Ad}}$ & - & & & & \\
\hline
\end{tabular}

There was no interaction $(P>0.05)$ between the pastoral environments and the periods (Table 4). In the pastoral environment analysis, a difference $(P<0.05)$ was observed for the bit rate performed by the grazing animals in the xaraés grass pasture, which was 7.74 bit. $\mathrm{min}^{-1}$ higher than that of the signal grass.

There was an interaction $(P<0.01)$ between the pastoral environments and time on the body surface temperatures of the anatomical regions (Table 5). The animals' body temperature at $1600 \mathrm{~h}$ in signal grass was higher in all the anatomical areas evaluated. According to the schedule, each treatment's surface temperature was variable, presenting higher average values at 12:00 $\mathrm{h}$ in pastoral environments. The lowest mean values for body surface temperatures were recorded at 00:00 and 04:00 $\mathrm{h}$ in the signal grass and from 20:00 to 04:00 $\mathrm{h}$ in the xaraés grass $(P>0.05)$. There was an interaction $(P<0.01)$ between pastoral environments and time variation of the surface temperature between the right and left. In pasture grass at 08:00 $\mathrm{h}$, a higher temperature was registered on the left flank (a difference of $3.27^{\circ} \mathrm{C}$ ), and at $12: 00 \mathrm{~h}$, a higher temperature was registered on the right flank $\left(1.30^{\circ} \mathrm{C}\right)$. In the time analysis in signal grass, the highest values were recorded at 12:00 $\mathrm{h}$, and the lowest was recorded at 16:00 h, while in xaraés the grass, the highest values were verified at $0800 \mathrm{~h}$. The other times did not differ $(P>0.05)$.

\section{Discussion}

The effect of climatic conditions can influence both the animals' behavioral responses and the body surface temperatures. In pastoral environments, the air temperature in specific periods was approximately $37^{\circ} \mathrm{C}$, and the $\mathrm{BGH}$ was about 92. According to Berman et al (1985) and Buffington et al (1981), these values indicate discomfort for the animals. However, Castro et al (2018) and Pereira et al (2018), evaluating lactating cows, stated that F1 Holstein $\times$ Zebu cows are tolerant to tropical environments, considered thermal stressors not present physiological and behavioral changes, and perform thermoregulation with efficiency to maintain milk production.

In the diurnal period, the highest values for BGHI were recorded, varying between 81 and 92 . During the same periods, the F1 Holstein $\times$ Zebu cows had a longer grazing time. Thus, the climatic environment did not influence the activity of searching for feed. On the other hand, the pasture influenced the ingestive behavior. The cows handled in the signal grass exhibited a time spent grazing that was 228 minutes greater than that in the pasture of xaraés grass. This was due to the structural characteristics and the chemicalbromatological composition favoring a high selectivity in signal grass, which is justified by the lower bit rate $(35.7$ bit. $\left.\min ^{-1}\right)$. Zanine et al (2009) observed a lower bit rate and longer grazing times for grazing cows managed in Coast-cross pasture, with 38.8 bit. $\mathrm{min}^{-1}$ and $622.8 \mathrm{~min} /$ day Marandu

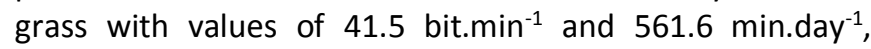
respectively. Brandão et al (2016) observed F1 Holstein $x$ Zebu steers behavior in Brachiaria brizantha cv. Marandu with protein-energetic or mineral supplementation did not find a significant difference for grazing, rumination, and idle times, with mean values of $636.3,404.45$, and 380.7 min.day 1 , respectively. These values corroborate those observed in this study. 
Table 3 Mean values of time spent on grazing, rumination, idleness, and other activities of F1 Holstein $\times$ Zebu cows in different pastoral environments

\begin{tabular}{|c|c|c|c|c|c|c|c|c|c|c|}
\hline \multirow{2}{*}{ Activities * } & \multirow{2}{*}{ Pastoral environments } & \multicolumn{5}{|l|}{ Períods } & \multirow[b]{2}{*}{ SEM } & \multicolumn{3}{|l|}{$P$-value } \\
\hline & & Morning & Afternoon & Night & Dawn & Total & & $\mathrm{T}$ & Per & $\mathrm{T} \times \mathrm{Per}$ \\
\hline \multicolumn{11}{|c|}{ Grazing (minutes) } \\
\hline & Signal grass ${ }^{1}$ & $237.90^{\mathrm{Ab}}$ & $258.90^{\mathrm{Aa}}$ & $139.40^{\mathrm{AC}}$ & $71.30^{\mathrm{Ad}}$ & $707.50^{\mathrm{A}}$ & \multirow{2}{*}{3.91} & \multirow{2}{*}{$<0.01$} & \multirow{2}{*}{$<0.01$} & \multirow{2}{*}{$<0.01$} \\
\hline & Xaraés grass ${ }^{2}$ & $176.00^{\mathrm{Bb}}$ & $193.70^{\mathrm{Ba}}$ & $84.00^{\mathrm{BC}}$ & $25.80^{\mathrm{Bd}}$ & $479.50^{\mathrm{B}}$ & & & & \\
\hline \multicolumn{11}{|c|}{ Rumination (minutes) } \\
\hline & Signal grass ${ }^{1}$ & $91.10^{\mathrm{Ac}}$ & $65.80^{\mathrm{Bd}}$ & $172.10^{\mathrm{Ab}}$ & $199.00^{\mathrm{Aa}}$ & $528.00^{A}$ & \multirow{2}{*}{3.96} & \multirow{2}{*}{0.14} & \multirow{2}{*}{$<0.01$} & \multirow{2}{*}{$<0.01$} \\
\hline & Xaraés grass ${ }^{2}$ & $87.70^{\mathrm{Ad}}$ & $99.70^{A c}$ & $170.00^{\mathrm{Ab}}$ & $182.00^{\mathrm{Ba}}$ & $539.40^{A}$ & & & & \\
\hline \multicolumn{11}{|c|}{ Idleness (minutes) } \\
\hline & Signal grass ${ }^{1}$ & $25.70^{\mathrm{BC}}$ & $23.20^{\mathrm{BC}}$ & $39.80^{\mathrm{Bb}}$ & $88.60^{\mathrm{Ba}}$ & $177.30^{\mathrm{B}}$ & \multirow{2}{*}{4.13} & \multirow{2}{*}{$<0.01$} & \multirow{2}{*}{$<0.01$} & \multirow{2}{*}{$<0.01$} \\
\hline & Xaraés grass ${ }^{2}$ & $92.70^{\mathrm{Ab}}$ & $46.80^{\mathrm{Ac}}$ & $98.90^{\mathrm{Ab}}$ & $151.60^{\mathrm{Aa}}$ & $390.00^{A}$ & & & & \\
\hline \multicolumn{11}{|c|}{ Other activities (minutes) } \\
\hline & Xaraés grass ${ }^{2}$ & $2.70^{\mathrm{Bb}}$ & $5.50^{\mathrm{Ba}}$ & $1.10^{\mathrm{Bb}}$ & $0.60^{\mathrm{Ab}}$ & $2.70^{\mathrm{B}}$ & 0.93 & $<0.01$ & $<0.01$ & $<0.01$ \\
\hline
\end{tabular}

*Ingestive Behavior Activities

1 Urochloa decumbens cv. Basilisk; 2 Urochloa brizantha cv. Xaraés

SEM: standard error of the mean; T: treatment (Pastoral environments); Per: períod; T $\times$ Per: interaction treatment versus period. $P$ - probability

Means followed by different letters uppercase in the row and lowercase in the column differ by Tukey's test $(P<0.05)$.

Feeding associated with climatic conditions interferes with rumination time, reducing when animals are under caloric stress (Soriani et al 2013; Moretti et al 2017). Rumination time was concentrated at night $(73 \%)$ when the animals are in a condition of thermal comfort. The lowest mean rumination times were recorded during the diurnal period when the animals continued grazing. Similar results were verified by Pereira et al (2018) with F1 cows in lactation, thus reaffirming F1 Holstein $\times$ Zebu cows' rusticity and adaptability to environments classified as thermal stressors. Zanine et al (2007) also observed approximately 70\% nocturnal rumination activity. However, there was a difference between the forages; in the Brachiaria brizantha pasture, they presented mean values of 477.0 min.day $^{-1}$; in Signal grass was 387.0 min. day ${ }^{-1}$.

Idleness can increase when the animals are in heat stress because this is antagonistic to other activities or after rumination to allow the absorption of the nutrients acquired throughout the day (Pereira et al 2018), a condition verified at two in the morning. The animal's heat production can be derived from the environment (solar radiation, temperature, humidity, and wind speed) through feeding and movement (Brosh et al 1998). Montanholi et al (2008) reported that infrared thermography may be a tool to predict the external environment's influence on endogenous heat production. Thus, fluctuations in body surface temperature were observed in all anatomical parts of the animals according to the time of day due to the ambient's constant heat exchanges. The evaluated animals have mostly black haircoat and black skin, which is favorable to the animal due to the maximum absorption of solar radiation. Although higher values of $\mathrm{BGH}$ occurred during the day, the haircoat can absorb and accumulate the heat; therefore, the body surface temperatures were higher in the afternoon. Due to heterosis benefits, these animals could dissipate the absorbed heat faster without altering their feed search since grazing occurred during the daytime period. Gonzalez-Rivas et al (2016) and Kou et al (2017) evaluated diets with slow fermenting grains and observed the surface temperatures of Simental cows in the winter, summer, and autumn seasons. They observed elevated surface temperatures between 1200 and $1600 \mathrm{~h}$. The same behavior was observed in this experiment with F1 Holstein $\times$ Zebu cows, with temperatures ranging from 37.0 to $40.4{ }^{\circ} \mathrm{C}$.

The proximity of the left flank to the rumen makes the location of this part of the body an indicator of temperature variations within the rumen, while the right flank of the animal's body reflects the temperature of the body core (Laure and Petersen 1991; Montanholi et al 2008). At 08:00 h in signal grass, the flanks' relationship was negative due to the more intense movement of these animals searching for feed. Based on observations in loco, it was verified that cows managed on pasture began grazing at approximately 05:00 $\mathrm{h}$. Thus, when thermographic records were obtained at 08:00 h, these animals had intense ruminal activity. According to Montanholi et al (2008), the body surface temperature increases 2 to 3 hours after each feeding. After 15:00, there is a reduction in the surface temperature at different points on the body. In xaraés grass, grazing started at 07:00, the exact moment as thermographic recording, and the animals were in greater movement, which increases the peripheral blood flow without intense ruminal activity (Montanholi et al 2008).

At 12:00 $\mathrm{h}$, when the $\mathrm{BGHI}$ recorded was approximately 92, the relationship between the flanks was positive, indicating the thermal environment's activity on body surface temperature. At the same time, in the xaraés grass pasture, the relationship between the sides was zero, indicative of a ruminal movement that began later than that in the signal grass pasture, in addition to climate change. At 1200 and $1600 \mathrm{~h}$, when the highest grazing times occurred, the highest values of temperature for the right and left flanks 
were recorded, indicating that, although the thermal environment increases body surface temperatures, F1 Holstein $\times$ Zebu cows do not stop grazing.

The F1 Holstein $\times$ Zebu cows managed in a pasture environment formed by deferred signal grass at the beginning of regrowth present a longer grazing time and a lower bit rate than cows managed in vegetative growth grasses. The animals' body surface temperature measured by infrared thermography varies throughout the day but does not interfere with grazing time in crossbred cows.

Table 4 Mean values of bit rate (bit.minutes ${ }^{-1}$ ) of F1 Holstein $\times$ Zebu cows.

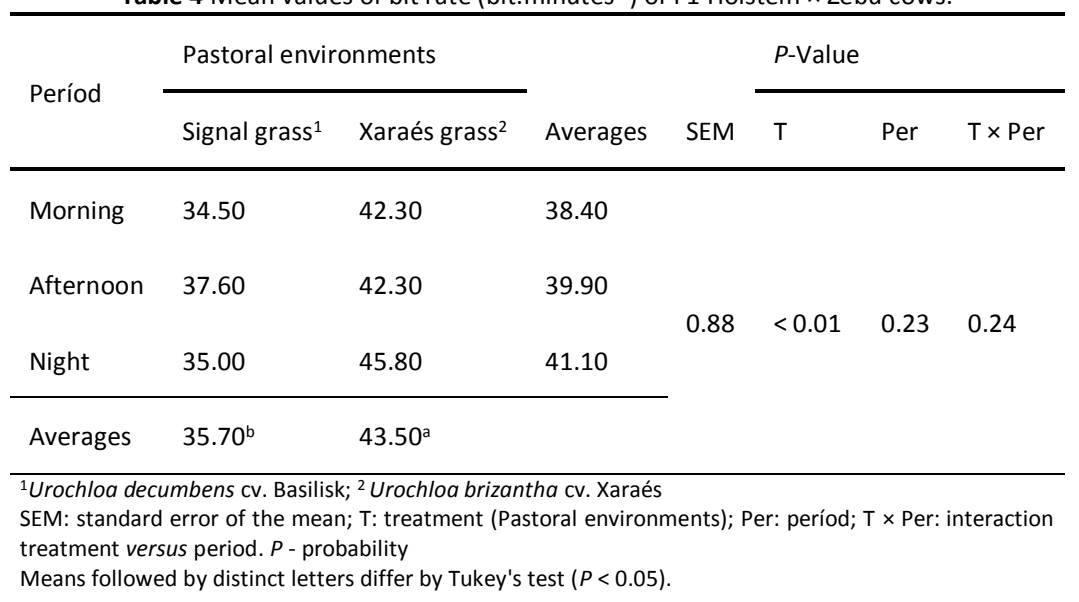

Table 5 Mean values of F1 Holstein $\times$ Zebu cows' body surface temperature in different anatomical regions and difference between the right and left flank.

\begin{tabular}{|c|c|c|c|c|c|c|c|c|c|c|c|}
\hline \multirow{2}{*}{$\begin{array}{l}\text { Anatomical } \\
\text { regions }\end{array}$} & \multirow{2}{*}{ Pastoral environments } & \multicolumn{6}{|l|}{ Hours } & \multirow[b]{2}{*}{ SEM } & \multicolumn{3}{|c|}{$P$-value } \\
\hline & & 08:00 & $12: 00$ & $16: 00$ & $20: 00$ & $00: 00$ & 04:00 & & $\mathrm{T}$ & Per & $\mathrm{T} \times \mathrm{Per}$ \\
\hline \multicolumn{12}{|c|}{ Right flank $\left({ }^{\circ} \mathrm{C}\right)$} \\
\hline & Signal grass ${ }^{1}$ & $35.20^{\mathrm{Bb}}$ & $39.40^{\mathrm{Ba}}$ & $39.00^{\mathrm{Aa}}$ & $33.10^{\mathrm{AC}}$ & $31.80^{\mathrm{Ad}}$ & $31.00^{\mathrm{Bd}}$ & \multirow{2}{*}{0.31} & \multirow{2}{*}{$<0.01$} & \multirow{2}{*}{$<0.01$} & \multirow{2}{*}{$<0.01$} \\
\hline & Xaraés grass ${ }^{2}$ & $38.20^{\mathrm{Ab}}$ & $40.40^{\mathrm{Aa}}$ & $37.00^{\mathrm{BC}}$ & $32.90^{\mathrm{Ad}}$ & $32.10^{\mathrm{Ad}}$ & $32.30^{\mathrm{Ad}}$ & & & & \\
\hline \multicolumn{12}{|c|}{ Left flank $\left({ }^{\circ} \mathrm{C}\right)$} \\
\hline & Signal grass ${ }^{1}$ & $35.40^{A C}$ & $38.10^{\mathrm{Bb}}$ & $39.50^{\mathrm{Aa}}$ & $33.30^{\mathrm{Ad}}$ & $31.60^{\mathrm{Ae}}$ & $31.00^{\mathrm{Ae}}$ & \multirow[b]{2}{*}{0.29} & \multirow[b]{2}{*}{0.09} & \multirow{2}{*}{$<0.01$} & \multirow[b]{2}{*}{$<0.01$} \\
\hline & Xaraés grass ${ }^{2}$ & $35.20^{\mathrm{Ac}}$ & $40.40^{\mathrm{Aa}}$ & $37.00^{\mathrm{Bb}}$ & $33.20^{\mathrm{Ad}}$ & $32.10^{\mathrm{Ad}}$ & $32.50^{\mathrm{Ad}}$ & & & & \\
\hline \multicolumn{12}{|c|}{ Difference between right and left flank $\left({ }^{\circ} \mathrm{C}\right)$} \\
\hline & Signal grass ${ }^{1}$ & $-0.20^{\mathrm{Bab}}$ & $1.30^{\mathrm{Aa}}$ & $-0.50^{\mathrm{Ab}}$ & $-0.20^{\text {Aab }}$ & $0.20^{\mathrm{Aab}}$ & $0.00^{\mathrm{Aab}}$ & 0.40 & 0.15 & $<0.01$ & $<0.01$ \\
\hline
\end{tabular}

${ }^{1}$ Urochloa decumbens cv. Basilisk; ${ }^{2}$ Urochloa brizantha cv. Xaraés

SEM: standard error of the mean; T: treatment (Pastoral environments); Per: period; $\mathrm{T} \times$ Per: interaction treatment versus period. $P$ - probability

Means followed by different letters uppercase in the row and lowercase in the column differ by Tukey's test $(P<0.05)$.

\section{Conclusions}

The F1 Holstein $\times$ Zebu cows managed in a pasture environment formed by deferred signal grass at the beginning of regrowth present a longer grazing time and a lower bit rate than cows managed in vegetative growth grasses. The animals' body surface temperature measured by infrared thermography varies throughout the day but does not interfere with grazing time in crossbred cows.

\section{Conflict of Interest}

The authors declare that they have no conflict of interest.

\section{Funding}

This study was financed in part by the Coordenação de Aperfeiçoamento de Pessoal de Nível Superior - Brasil (CAPES) - Finance Code 001. To EPAMIG for the availability of the site and the animals, to FAPEMIG, for the financial support (PPM 00558-16); to Finepe and MCTI, for the financial support to project no 1334/13; to INCT- Animal Science and Universidade Estadual de Montes Claros.

\section{References}

Berman A, Folman Y, Kaim M, Mamen M, Herz Z, Wolfenson D, Arieli A, Graber $Y$ (1985) Upper critical temperatures and forced ventilation effects for high-yielding dairy cows in a subtropical climate. Journal of Dairy Science 68:1488-1495.

Brandão RKC, Carvalho GGP, Silva RR, Dias DLS, Mendes FBL, Lins TOJD'A, Filho GA, Souza SO, Barroso DS, Rufino LMA, and Tosto MSL (2016) Comparison of protein and energy supplementation to mineral supplementation on feeding behavior of grazing cattle during the rainy to the dry season transition; SpringerPlus 5:933.

Brosh A, Aharoni Y, Degen AA, Wright D and Young BA (1998) Effects of solar radiation, dietary energy, and time of feeding on thermoregulatory responses and energy balance in cattle in a hot environment. Journal of Animal Science 76:2671-2677. 
Buffington DE, Collazo Arocho A, Canton GH, Pitt D, Thatcher WW, Collier RJ (1981) Black globe humidity index (BGHI) as a comfort equation for dairy cows. Transactions of the ASAE 24:711- 714.

Castelán-Ortega AO, Martinez-Garcia CG, Mould FL, Dorward P, Miranda-de La Lama GC, Cruz-Monterrosa RG and Rayas-Amor AA (2016) Grazing behaviour of dairy cows and body condition score associated with sward characteristics of four pasture types. Experimental Agriculture. doi:10.1017/S001447971600020X

Castro ALO, Carvalho CCS, Ruas JRM, Pereira KCB, Menezes GCC and Costa MD (2018) Physiological parameters of F1 Holstein X Zebu cows raised in environments with and without shading. Brazilian Journal of Veterinary and Animal Science 70:722-730.

Dahl GE (2012) Impact of dry cow cooling on subsequent performance and health. In Proceedings 48th Florida Dairy Production Conference.

De Vries MFW (1995) Estimating forage intake and quality in grazing cattle: a reconsideration of the hand-plucking method. Journal of Range Management 48:370-375.

Detmann E, Souza MA, Valadares Filho SC, Queiroz AC, Berchielli TT, Saliba EOS, Cabral LS, Pina DS, Ladeira MM and Azevedo JAG (2012) Métodos para análises de alimentos-INCT-Ciência Animal. UFV,Viçosa.

Do Amaral BC, Connor EE, Tao S, Hayen J, Bubolz J and Dahl GE (2009) Heatstress abatement during the dry period: Does cooling improve transition into lactation?. Journal of Dairy Science 92:5988-5999.

Forbes TDA, Hodgson J (1985) Comparative studies of the influence of sward conditions on the ingestive behaviour of cows and sheep. Grass and Forage Science 40:69-77.

Gonzalez-Rivas PA, DiGiacomo K, Russo VM, Leury BJ, Cottrell JJ and Dunshea FR (2016) Feeding slowly fermentable grains has the potential to ameliorate heat stress in grain-fed wethers. Journal of Animal Science 94:2981-2991.

Kou H, Zhao Y, Ren K, Chen X, Lu Y and Wang D (2017) Automated measurement of cattle surface temperature and its correlation with rectal temperature. PloS one 12:e0175377.

Laüe HJ, Petersen U (1991) Relations between temperature changes in the rumen and roughage intake of dairy cows. Zuechtungskunde (Germany, FR).
Montanholi YR, Odongo NE, Swanson KC, Schenkel FS, McBride BW and Miller SP (2008) Application of infrared thermography as an indicator of heat and methane production and its use in the study of skin temperature in response to physiological events in dairy cattle (Bos taurus). Journal of Thermal Biology 33:468-475.

Moretti R, Biffani S, Chessa S and Bozzi R (2017) Heat stress effects on Holstein dairy cows' rumination. Animal 11:2320-2325.

Pereira KCB, Carvalho CCS., Ruas JRM, Menezes GCC., Castro ALO and Costa MD (2018) Effect of the climatic environment on ingestive behavior of F1 Holstein x Zebu cows. Brazilian Journal of Animal Health and Production 19:207-215.

Ruas JRM, Silva EA, Queiroz DS, Pereira MEG, Soares Júnior JAG, Santos MD and Rocha Júnior VR (2014) Lactation productive characteristics of four genetic groups F1 Holstein x Zebu. Brazilian Journal of Veterinary Science 21:33-37.

Santos MER, Fonseca DM, Balbino EM, Monnerat JPIS and Silva SP (2009) Deferred and fertilized signalgrass: forage production and characteristics. Brazilian Journal of Animal Science 38:650-656.

Soriani N, Panella G and Calamari L (2013) Rumination time during the summer season and its relationships with metabolic conditions and milk production. Journal of Dairy Science 96:5082-5094.

Tao S, Bubolz JW, Do Amaral BC, Thompson IM, Hayen MJ, Johnson SE and Dahl GE (2011) Effect of heat stress during the dry period on mammary gland development. Journal of Dairy Science 94:5976-5986.

Zanine AM, Santos EM, Parente HN, Ferreira DJ and Cecon, PR (2007) Grazing behavior of Holstein $\times$ Zebu lactating cows in pastures of Brachiaria brizantha and Brachiaria decumbens. Brazilian Journal of Veterinary and Animal Science 59:175-181.

Zanine AM, Vieira BR, Ferreira DDJ, Vieira AJM, Lana RDP and Cecon PR (2009) Ingestive behavior of Gyrx Holstein cows grazing "Brachiaria brizantha" and Coast-cross pastures. Brazilian Journal of Animal Health and Production 10:85-95. 